\title{
PENINGKATAN KOMPETENSI PEDAGOGIK GURU SDN GELAM 1 KABUPATEN SIDOARJO DALAM MENYUSUN RPP BERBASIS PPK MELALUI IN HOUSE TRAINING
}

\author{
Ruqoiyah \\ SDN Gelam 1 Sidoarjo \\ ruqoiyah1963@gmail.com
}

\begin{abstract}
ABSTRAK
Penelitian ini dilatarbelakangi belum tercapainya kompetensi pedagogik guru SDN Gelam 1 dalam menyusun RPP berbasis Penguatan Pendidikan Karakter (PPK). Penyebabnya guru belum memahami komponen dan prinsip-prinsip penyusunan RPP. Hasil RPP yang disusun guru masih banyak yang belum lengkap. RPP yang disusun guru belum mengintegrasikan PPK. Untuk meningkatkan kompetensi pedagogik guru diperlukan upaya perbaikan melalui In House Training. Penelitian ini menggunakan pendekatan penelitian tindakan sekolah (PTS). Subyek penelitian di sini adalah guru SDN Gelam 1 dengan jumlah 8 orang. Hasil penelitian menunjukkan bahwa keterlaksanaan program kegiatan IHT terbukti efektif dalam meningkatkan kompetensi pedagogik guru pada siklus I sebesar 81 meningkat siklus II sebesar 90. Penerapan IHT terbukti dapat meningkatkan kompetensi pedagogik guru dari presentase pra tindakan sebesar $21 \%$, meningkat siklus I sebesar 79\%, dan meningkat secara signifikan siklus II sebesar 93\%. Dapat disimpulkan bahwa penerapan IHT dapat meningkatkan kompetensi pedagogik guru SDN Gelam 1 dalam menyusun RPP berbasis PPK.
\end{abstract}

Katakunci : In House Training, Kompetensi Pedagogik, RPP Berbasis PPK.

\section{ABSTRACT}

This research background by an underachieving pedagogic competence of elementary school teachers Gelam 1 in drafting lesson plans (RPP) based on character education (PPK). The reason teachers have not understood the components and principles of lesson plans drafting. There are still many incomplete lesson plans developed by the teacher. Lesson plan that drafted teachers have not integrated with chracter education. To improve the pedagogic competence of teachers necessary improvement efforts through In House Training. This research uses the school's action Research Approach (PTS). The subject of research here is the elementary school teacher Gelam 1 with a total of 8 people. The results showed that the implementation of the IHT activities program proved effective in improving the pedagogic competence of teachers in cycle I of 81 increased cycle II by 90 . The application of IHT is proven to increase the pedagogic competence of teachers from pre-action percentage by $21 \%$, increase cycle I by $79 \%$, and significantly increased cycle II by $93 \%$. It can be concluded that the application of IHT can improve the teacher pedagogic competence of Gelam 1 elementary school in drafting lesson plan based on character education.

Keywords: pedagogic competence, Lesson Plan Based on Character Education, In House Training.

\section{PENDAHULUAN}

Berdasarkan

Permendikbud

Nomor 22 Tahun 2016 tentang

Standar Proses Pendidikan Dasar dan

Menengah mengemukakan bahwa

setiap pendidik pada satuan pendidikan berkewajiban menyusun

Rencana Pelaksanaan Pembelajaran (RPP) secara lengkap dan sistematis agar pembelajaran berlangsung secara interaktif, inspiratif, menyenangkan, menantang, efisien, 
memotivasi peserta didik untuk berpartisipasi aktif, serta memberikan ruang yang cukup bagi prakarsa, kreativitas, dan kemandirian sesuai dengan bakat, minat, dan perkembangan fisik serta psikologis peserta didik. RPP disusun berdasarkan Kompetensi Dasar (KD) atau subtema yang dilaksanakan kali pertemuan atau lebih.

\section{Perencanaan pembelajaran}

berperan untuk mengarahkan suatu proses pembelajaran agar dapat menghantarkan peserta didik kepada tujuan pendidikan yang telah ditargetkan. Peranan perencanaan pembelajaran sangat diperlukan, karena itu merupakan keharusan yang harus dilalui oleh guru dalam melaksanakan pembelajaran di kelas. Perencanaan pembelajaran ini sangat penting menjadi pedoman bagi seorang guru agar mampu mengarahkan peserta didik untuk belajar dengan baik. Guru yang baik akan selalu membuat perencanaan dalam kegiatan pembelajarannya, maka tidak ada alasan mengajar di kelas tanpa perencanaan pembelajaran.

Dalam menyusun RPP, guru juga harus memperhatikan komponen dan prinsip-prinsip penyusunan RPP. Rencana pelaksanaan pembelajaran memuat sekurang-kurangnya tujuan pembelajaran, materi ajar, metode pengajaran, sumber belajar dan penilaian hasil belajar (Sanjaya, 2010:60). Jika salah satu komponen dihilangkan dapat dipastikan pembelajaran di kelas tidak akan berhasil dan tidak belajar dengan lancar. Oleh karena itu guru harus memperhatikan komponen tersebut dalam menyusun perencanaan pembelajaran sehingga pembelajaran yang direncanakan dapat berhasil dan berjalan sesuai tujuan pembelajaran.

Selain itu guru harus mengintegrasikan nilai-nilai karakter ke dalam penyusunan RPP. Implementasi PPK (Penguatan Pendidikan Karakter) dapat dilakukan melalui pendekatan berbasis kelas, salah satunya melalui penyusunan RPP. Mendesain RPP yang memuat fokus penguatan karakter dengan memilih metode pembelajaran dan pengelolaan (manajemen) kelas yang relevan. Pendidik memiliki kewenangan dalam mempersiapkan (sebelum masuk kelas), mengajar, dan setelah pengajaran, dengan mempersiapkan skenario pembelajaran yang berfokus pada nilai-nilai utama karakter (Hendarman, 2017:27).

Kompetensi yang harus dimiliki guru dalam menyusun perencanaan pembelajaran yaitu kompetensi pedagogik. Sebagaimana dalam Permendiknas Nomor 16 Tahun 2007 tentang Standar Kualifikasi Akademik dan Kompetensi Guru menjelaskan bahwa kompetensi pedagogik yang harus dimiliki guru meliputi: 1) memahami prinsip-prinsip perancangan pembelajaran yang mendidik; 2) mengembangkan komponen-komponen rancangan 
pembelajaran; 3) menyusun rancangan pembelajaran yang lengkap, baik untuk kegiatan di dalam kelas, laboratorium, maupun lapangan; 4) melaksanakan pembelajaran yang mendidik di kelas, di laboratorium, dan di lapangan dengan memperhatikan standar keamanan yang dipersyaratkan; 5) menggunakan media pembelajaran dan sumber belajar yang relevan dengan karakteristik peserta didik dan mata pelajaran yang diampu untuk mencapai tujuan pembelajaran secara utuh; 6) mengambil keputusan transaksional dalam pembelajaran yang diampu sesuai dengan situasi yang berkembang.

Penyusunan perencanaan pembelajaran banyak tergantung kepada kompetensi guru mengembangkannya, karena tugas guru berkaitan dengan melaksanakan pembelajaran yang menjadi tanggung jawabnya. Oleh karena itu, diperlukan perencanaan pembelajaran yang dapat mencapai keefektifan pembelajaran yang akan dilaksanakan. Dengan perencanaan pembelajaran guru akan mantap melaksanakan pembelajaran di kelas. Perencanaan yang matang dapat menimbulkan banyak inisiatif dan daya kreatif guru dalam mengajar dan dapat meningkatkan interaksi belajar mengajar antara guru dan siswa, serta pada akhirnya dapat meningkatkan hasil belajar siswa di kelas.

Perencanaan pembelajaran dapat memudahkan guru dalam mencapai tujuan pembelajaran yaitu membentuk manusia secara utuh, bukan hanya berkembang secara intelektual saja, akan tetapi juga dalam sikap dan keterampilan. Agar tujuan yang sudah direncanakan dapat tercapai diperlukan rancangan yang disesuaikan dengan kebutuhan/karakteristik peserta didik dan materi pembelajaran. Perencanaan pembelajaran yang dibuat merupakan antisipasi dan perkiraan yang akan dilakukan dalam pembelajaran, sehingga tercipta suatu situasi yang memungkinkan terjadinya proses belajar yang dapat mengantar siswa mencapai tujuan yang diharapkan (Sanjaya, 2010:35).

Berdasarkan hasil observasi pra tindakan, kompetensi pedagogik guru SDN Gelam 1 Kabupaten Sidoarjo dalam menyusun RPP berbasis PPK belum mencapai kompetensi yang dikehendaki. Hasil kompetensi pedagogik guru mendapatkan ratarata skor sebesar 64 dengan persentase mencapai $25 \%$ atau ada 2 orang guru yang sudah kompeten, sedangkan yang belum kompeten mencapai $75 \%$ atau ada 6 orang guru.

Masih belum tercapainya kompetensi pedagogik guru dalam menyusun RPP berbasis PPK disebabkan guru belum memahami komponen dan prinsip-prinsip penyusunan RPP. Hal ini terbukti dari hasil RPP yang disusun guru masih banyak yang belum lengkap seperti tidak adanya media pembelajaran, tidak ada lembar kerja maupun 
evaluasi beserta kunci jawabannya, dan tidak adanya instrumen penilaian beserta rubrik penilaiannya.

Selain itu dalam
mengembangkan indikator pencapaian kompetensi, guru masih kesulitan karena belum memahami taksonomi bloom hasil belajar aspek pengetahuan, sikap, dan keterampilan. Dalam langkah-langkah pembelajarannya pun belum menunjukkan sintaks model pembelajaran yang dipilih. Begitu juga RPP yang disusun guru belum mengintegrasikan penguatan pendidikan karakter, terlihat dari tujuan pembelajaran dan langkahlangkah pembelajarannya tidak mencantumkan pendidikan karakter. Padahal program tersebut diberlakukan cukup lama dan juga diberikan pada kegiatan pelatihan.

Dari hasil wawancara dengan sebagian guru menunjukkan bahwa RPP yang disusun hanya meng-copy paste atau membeli dari rekan sejawatnya dan juga ada yang mengambil (download) RPP dari internet. Hal ini dikarenakan guru enggan menyusun RPP karena banyak tugas yang harus dikerjakan sehingga dengan menyusun RPP dapat mengganggu proses belajar mengajar di kelas. Namun ada juga sebagian guru yang membuat RPP sendiri meskipun masih ada beberapa kelemahan-kelemahan seperti yang sudah dijelaskan di atas.

Sebagaimana permasalahan yang terjadi di atas, penulis tertarik untuk membantu guru memecahkan masalah dalam menyusun RPP berbasis PPK guna meningkatkan kompetensi pedagogik guru yang dipimpinnya. Hal tersebut sesuai dengan pendapat Mulyasa (2013:99), bahwa peran kepala sekolah adalah sebagai manajer, yaitu mengelola tenaga kependidikan salah satunya melaksanakan kegiatan pemeliharaan dan pengembangan profesi para guru. Dalam hal ini, kepala sekolah seyogyanya dapat memfasiltasi dan memberikan kesempatan yang luas kepada para guru untuk dapat melaksanakan kegiatan pengembangan profesi melalui berbagai kegiatan pendidikan dan pelatihan, baik yang dilaksanakan di sekolah atau melalui kegiatan pendidikan dan pelatihan di luar sekolah. Salah satu alternatif yang akan penulis lakukan dalam meningkatkan kompetensi pedagogik guru dalam menyusun RPP berbasis PPK yakni dengan menerapkan In House Training (IHT).

Pelatihan dalam bentuk IHT adalah pelatihan yang dilaksanakan secara internal di KKG/MGMP, sekolah atau tempat lain yang ditetapkan untuk menyelengggarakan pelatihan. Strategi pembinaan melalui IHT dilakukan berdasarkan pemikiran bahwa sebagian kemampuan dalam meningkatkan kompetensi dan karir guru tidak harus dilakukan secara eksternal, tetapi dapat dilakukan oleh guru yang memiliki kompetensi kepada guru lain yang belum memiliki 
kompetensi. Dengan strategi ini diharapkan dapat lebih menghemat waktu dan biaya. Ketentuan peserta dalam IHT minimal 4 orang dan maksimal 15 orang (Depdikbud, 2015:19).

Sebagaimana Nurtain (dalam Depdikbud, 2015:26-28) menjelaskan bahwa tujuan pelatihan dalam bidang pendidikan antara lain: 1) untuk peningkatan program pengajaran dan proses belajar mengajar sehingga dapat ikut mendorong perkembangan pendidikan; 2) memperkenalkan guru-guru dengan berbagai sumber media dan materialnya (audio visual aid); 3) memantapkan sedikitnya empat kompetensi, yaitu kompetensi pengetahuan akademis, kompetensi pengetahuan profesional, kompetensi seni dan keterampilan teknis, dan keterampilan bermasyarakat; 4) membekali guru secara konstan sesuai dengan perubahan-perubahan dalam pengembangan kurikulum sekolah; 5) lebih memperluas pengetahuan akademis, profesional dan teknis baik dalam bentuk isi, metode maupun keterampilan yang harus dikuasai; 6) membuka kesempatan bagi guru-guru untuk mengembangkan dirinya sendiri secara profesional.

Berdasarkan ulasan latar belakang masalah tersebut, maka dilakukan suatu penelitian tindakan sekolah (PTS) dengan judul "Peningkatan Kompetensi Pedagogik Guru SDN Gelam 1 Kabupaten Sidoarjo dalam Menyusun RPP
Berbasis PPK melalui In House Training".

Berdasarkan latar belakang masalah yang telah diuraikan di atas dapat dirumuskan permasalahan sebagai berikut: 1) Bagaimana efektifitas keterlaksanaan program kegiatan In House Training terhadap peningkatan kompetensi pedagogik guru SDN Gelam 1 Kabupaten Sidoarjo dalam menyusun RPP berbasis PPK?; 2) Apakah penerapan In House Training dapat meningkatkan kompetensi pedagogik guru SDN Gelam 1 Kabupaten Sidoarjo dalam menyusun RPP berbasis PPK?

Berdasarkan uraian perumusan masalah di atas dapat disimpulkan tujuan penelitian sebagai berikut: 1) Untuk mengetahui efektifitas keterlaksanaan program kegiatan In House Training terhadap peningkatan kompetensi pedagogik guru SDN Gelam 1 Kabupaten Sidoarjo dalam menyusun RPP berbasis PPK; 2) Untuk mengetahui peningkatan kompetensi pedagogik guru SDN Gelam 1 Kabupaten Sidoarjo dalam menyusun RPP berbasis PPK melalui In House Training.

\section{METODE PENELITIAN}

Rancangan penelitian yang digunakan adalah model Penelitian Tindakan Sekolah (PTS). Menurut Arikunto (2010:135), mengemukakan bahwa penelitian tindakan sekolah (school action research) adalah penelitian yang dilakukan oleh pihak pengelola sekolah sebagai sebuah 
organisasi pendidikan untuk meningkatkan kinerja, proses, dan produktivitas lembaga.

Adapun model PTS yang dikemukakan oleh Kemmis \& Mc Taggart (dalam Arikunto, 2010:97), menggambarkan adanya empat langkah dan pengulangnya, yang disajikan berikut ini.

1. Tahap 1 : Perencanaan

Pada tahap perencanaan ini penulis melakukan kegiatan perencanaan antara lain: 1) Berkoordinasi dengan pengawas sekolah atau mitra kolaborator yang bertugas membantu pelaksanaan kegiatan In House Training (IHT); 2) Melakukan sosialisasi kepada guru-guru, menentukan jadwal dan waktu pelaksanaannya, serta menentukan jumlah peserta; 3) Menyusun program kegiatan; 4) Membuat SK kepanitiaan, daftar hadir, dan undangan; 5) Menyiapkan materi dan contoh RPP berbasis PPK dalam bentuk poweropoint dan hand out; 6) Menyusun instrumen peningkatan kompetensi pedagogik guru dan instrumen keterlaksanaan program.

2. Tahap 2 : Pelaksanaan Tindakan Pada tahap pelaksanaan tindakan dalam penelitian ini dengan melaksanakan perencanaan yang telah dibuat, yakni dengan melaksanakan kegiatan IHT dalam meningkatkan kompetensi pedagogik guru dalam menyusun

RPP berbasis PPK. Penelitian ini dilaksanakan dalam dua siklus, masing-masing siklus terdiri dari kegiatan pendahuluan, kegiatan inti, dan kegiatan penutup.

3. Tahap 3 : Pengamatan Pada tahap pengamatan dalam penelitian ini dilaksanakan secara kolaboratif untuk mengamati kegiatan IHT dalam meningkatkan kompetensi pedagogik guru dalam menyusun RPP berbasis PPK. Pada saat pengamatan penulis bersama mitra kolaborator mengamati hasil RPP berbasis PPK yang dibuat guru dan mencocokkannya dengan instrumen peningkatan kompetensi pedagogik guru secara objektif dan transparan. Di akhir kegiatan pengamatan, penulis membagikan instrumen keterlaksanaan program kepada seluruh guru untuk mengetahui efektifitas pelaksanaan kegiatan IHT.

4. Tahap 4 : Refleksi

Pada tahap refleksi dalam penelitian ini, penulis mengkaji peningkatan kompetensi pedagogik guru dalam menyusun RPP berbasis PPK melalui IHT. Penulis juga mengkaji apakah program kegiatan sudah berjalan efektif dengan mencatat kelemahan yang muncul selama pelaksanaan tindakan dan memberikan saran perbaikan hasil pengamatan. Setelah itu, penulis dan mitra kolaborator membuat perencanaan tindak lanjut untuk 
siklus berikutnya berdasarkan daftar permasalahan tersebut, dalam rangka perbaikan untuk mencapai indikator yang ditetapkan.

\section{Subyek dan Lokasi Penelitian}

Dalam penelitian ini yang dijadikan subyek penelitian adalah guru-guru SDN Gelam 1 Kabupaten Sidoarjo Tahun Pelajaran 2018-2019, dengan jumlah 8 guru yang terdiri dari 2 guru laki-laki dan 6 guru perempuan. Tempat penelitian berada di SDN Gelam 1 yang berlokasi di Jalan Raya Gelam No. 49 Desa Gelam Kecamatan Candi Kabupaten Sidoarjo Kode Pos 61271. Pemilihan SDN Gelam 1 sebagai tempat penelitian merupakan satuan pendidikan tempat peneliti bekerja sebagai kepala sekolah. Waktu penelitian dilaksanakan pada bulan September sampai dengan Nopember 2018.

\section{Teknik Pengumpulan Data}

Teknik pengumpulan data pada penelitian ini menggunakan teknik observasi, wawancara, dokumentasi, dan catatan lapangan yang dijelaskan sebagai berikut.

Teknik observasi digunakan untuk mengetahui peningkatan kompetensi pedagogik guru dan efektifitas keterlaksanaan program kegiatan IHT pada tiap siklus. Teknik observasi dilakukan dengan langkahlangkah antara lain: (1) Menyediakan instrumen peningkatan kompetensi pedagogik guru dan instrumen keterlaksanaan program; (2) Memberikan tugas menyusun RPP berbasis PPK kepada seluruh subyek penelitian; (3) Menelaah hasil penyusunan RPP berbasis PPK yang disusun subyek penelitian berdasarkan pedoman instrumen peningkatan kompetensi pedagogik guru; (4) Di akhir kegiatan, membagikan instrumen keterlaksanaan program kepada seluruh subyek penelitian; (5) Menghitung skor perolehan pada instrumen peningkatan kompetensi pedagogik guru dan instrumen keterlaksanaan program setiap guru atau subyek penelitian.

Teknik wawancara digunakan untuk mendapatkan informasi tentang seberapa jauh respon guru menguasai kompetensi pedagogik dalam menyusun RPP berbasis PPK. Teknik wawancara dilakukan dengan langkah-langkah antara lain: Menyiapkan pedoman wawancara; (2) Melakukan wawancara dengan subyek penelitian mengacu pada daftar pertanyaan yang disediakan; (3) Mencatat seluruh jawaban subyek penelitian ke dalam lembar yang disediakan.

Teknik dokumentasi foto digunakan untuk menjelaskan keruntutan penelitian dari awal sampai akhir. Teknik dokumentasi dilakukan dengan langkah-langkah antara lain: (1) Menyiapkan media (kamera) yang akan digunakan untuk mendokumentasikan kegiatan; 
Memotret setiap kegiatan/ aktivitas penelitian; (3) Memilah dan memilih foto yang akan digunakan dalam penelitian ini.

Teknik catatan lapangan ini digunakan untuk merefleksi segala program kegiatan IHT yang telah dilakukan agar program kegiatan IHT pada siklus berikutnya dapat berhasil dan sesuai dengan yang diharapkan. Teknik catatan lapangan dilakukan dengan langkah-langkah antara lain: (1) Menyiapkan lembar catatan lapangan dan petunjuk pengisiannya; (2) Mencatat kelebihan dan kekurangan penelitian; dan (3) Merefleksikan kelebihan dan kekurangan sebagai bahan perbaikan atau tindak lanjut.

\section{Teknik Analisis Data}

Teknik kuantitatif dilakukan untuk menganalisis peningkatan kompetensi pedagogik guru dalam menyusun RPP berbasis PPK melalui IHT pada siklus I dan siklus II. Skor yang diperoleh seluruh subyek penelitian setiap akhir siklus dijumlahkan, kemudian jumlah tersebut dihitung persentase. Analisis data tersebut dilakukan dengan langkah-langkah sebagai berikut.

1. Menelaah dan menghitung skor hasil penyusunan RPP berbasis PPK berdasarkan pedoman instrumen observasi dengan rumus:

skor $=\frac{\text { jumlah skor yang dicapai }}{\text { jumlah skor maksimal }} \times 100 \%$
2. Merekapitulasi skor hasil penyusunan RPP berbasis PPK setiap guru yang sudah dinilai pada tabel yang sudah disediakan.

3. Mengkategorikan skor hasil penyusunan RPP berbasis PPK setiap guru dengan kriteria ketuntasan kompetensi guru.

4. Menghitung persentase kompetensi pedagogik guru dengan rumus:

$$
\mathrm{SP}=\frac{\mathrm{SK}}{\mathrm{R}} \times 100 \%
$$

\section{Keterangan:}

SP : Skor Persentase

SK : Skor Kumulatif

$\mathrm{R}$ : Jumlah Responden

Setelah menganalisis hasil observasi kompetensi pedagogik guru dalam menyusun RPP berbasis PPK, hasil persentase dikategorikan dengan pedoman yang sudah ditetapkan sebagai berikut.

Tabel 1. Kategori Kompetensi Pedagogik Guru

\begin{tabular}{|c|c|}
\hline Kriteria & Rentang Skor \\
\hline Amat Baik & $86-100$ \\
\hline Baik & $71-85$ \\
\hline Cukup & $55-70$ \\
\hline Kurang & $0-54$ \\
\hline \multicolumn{2}{|c|}{ Sumber: Data Primer (2018) }
\end{tabular}

Teknik kualitatif digunakan untuk menganalisis hasil observasi, catatan lapangan, wawancara, dan dokumentasi foto pada program kegiatan IHT untuk meningkatkan kompetensi pedagogik guru dalam menyusun RPP berbasis PPK pada 
siklus I dan II. Langkah-langkah analisis data kualitatif, antara lain:

1. Menganalisis instrumen peningkatan kompetensi pedagogik guru yang telah diisi oleh pengamat (observer), kemudian mendeskripsikan hasil observasi ke dalam bentuk kalimat pada tiap siklus.

2. Menganalisis instrumen keterlaksanaan program yang telah diisi oleh subyek penelitian diakhir program, kemudian mendeskripsikan hasil observasi ke dalam bentuk kalimat pada tiap siklus.

3. Menganalisis data wawancara dengan cara membaca kembali hasil wawancara dan mendeskripsikannya dalam bentuk kalimat.

4. Menganalisis catatan lapangan penelitian dengan menulis kelebihan dan kelemahan dan mendeskripsikan dalam bentuk kalimat pada tiap siklus.
5. Menganalisis data hasil dokumentasi foto dengan cara mendeskripsikan gambar foto ke dalam bentuk kalimat pada tiap siklus.

Data hasil observasi, catatan lapangan, wawancara, dan dokumentasi foto tiap siklus dibandingkan. Dari hasil perbandingan akan diketahui peningkatan kompetensi pedagogik guru dan keterlaksanaan program IHT dalam menyusun RPP berbasis PPK dan dianalisis dengan analisa deskriptif kualitatif.

\section{HASIL PENELITIAN DAN \\ PEMBAHASAN \\ Hasil Penelitian \\ Pra Tindakan}

Sebelum menampilkan hasil penelitian, terlebih dahulu ditampilkan hasil kompetensi pedagogik guru SDN Gelam 1 dalam menyusun RPP berbasis PPK yang digunakan sebagai data awal.

Tabel 2.

Rekapitulasi Kompetensi Pedagogik Guru dalam Menyusun RPP berbasis PPK Pada Pra Tindakan

\begin{tabular}{|c|c|c|c|c|}
\hline Kategori & Respoden & NA & Persen (\%) & Ket. \\
\hline Amat Baik & 0 & 0 & $0 \%$ & \multirow{5}{*}{$\begin{array}{l}\frac{515}{8}=64,375 \\
\text { Kategori: Cukup }\end{array}$} \\
\hline Baik & 2 & 160 & $25 \%$ & \\
\hline Cukup & 3 & 195 & $37,5 \%$ & \\
\hline Kurang & 3 & 159 & $37,5 \%$ & \\
\hline Jumlah & 8 & 515 & $100 \%$ & \\
\hline
\end{tabular}

Sumber : Hasil Penelitian diolah (2018)

Pada tabel 2 terlihat bahwa kompetensi pedagogik guru SDN Gelam 1 dalam menyusun RPP berbasis PPK belum mencapai kompetensi yang dikehendaki. Hasil kompetensi pedagogik guru sebelum 
dilaksanakan program kegiatan IHT mendapat skor rata-rata sebesar 64 yang termasuk dalam kategori Cukup yaitu berada pada rentang skor 55-70. Perolehan kategori amat baik dengan nilai antara 86-100 sebanyak 0 orang guru atau $0 \%$. Kategori baik dengan nilai antara 71-85 sebanyak 2 orang guru atau 25\%. Kategori cukup dengan nilai antara 55-70 sebanyak 3 orang guru atau 37,5\%. Kategori kurang dengan nilai antara $0-54$ sebanyak 3 orang guru atau $37,5 \%$. Persentase pencapaian kompetensi pedagogik guru pada pra tindakan mencapai $25 \%$ atau ada 2 orang guru yang sudah kompeten, sedangkan yang belum kompeten mencapai $75 \%$ atau ada 6 orang guru. Hasil tersebut menunjukkan bahwa pada pra tindakan secara klasikal belum mencapai kompetensi yang dikehendaki.

\section{Siklus I}

Berdasarkan analisis instrumen keterlaksanaan program kegiatan dapat diketahui hasil keterlaksanaan program kegiatan IHT siklus I, sebagai berikut.

Tabel 3.

Rekapitulasi Keterlaksanaan Program Kegiatan IHT Siklus I

\begin{tabular}{|c|c|c|c|c|}
\hline Kategori & Respoden & NA & Persen (\%) & Ket. \\
\hline Amat Baik & 3 & 264 & $37,5 \%$ & \multirow{5}{*}{$\begin{array}{l}\frac{641}{8}=80,125 \\
\text { Kategori: Baik }\end{array}$} \\
\hline Baik & 3 & 246 & $37,5 \%$ & \\
\hline Cukup & 2 & 131 & $25 \%$ & \\
\hline Kurang & 0 & 0 & $0 \%$ & \\
\hline Jumlah & 8 & 641 & $100 \%$ & \\
\hline
\end{tabular}

Sumber : Hasil Penelitian diolah (2018)

Tabel 3 menunjukkan bahwa hasil keterlaksanaan program kegiatan IHT pada siklus I mendapatkan rata-rata nilai klasikal sebesar 80 yang termasuk dalam kategori Baik yaitu berada pada rentang nilai 71-85. Perolehan kategori amat baik dengan nilai antara 86-100 sebanyak 3 responden atau $37,5 \%$. Kategori baik dengan nilai antara 71-85 sebanyak 3 responden atau $37,5 \%$. Kategori cukup dengan nilai antara 55-70 sebanyak 2 responden atau $25 \%$. Kategori kurang dengan nilai antara 0-54 sebanyak 0 responden atau $0 \%$.

Berdasarkan analisis instrumen peningkatan kompetensi pedagogik guru dapat diketahui hasil peningkatan kompetensi pedagogik guru dalam menyusun RPP berbasis PPK melalui IHT pada siklus I, sebagai berikut. 
Tabel 4.

Rekapitulasi Kompetensi Pedagogik Guru dalam Menyusun RPP berbasis PPK Pada Siklus I

\begin{tabular}{|c|c|c|c|c|}
\hline Kategori & Respoden & NA & Persen (\%) & Ket. \\
\hline Amat Baik & 3 & 273 & $37,5 \%$ & \multirow{5}{*}{$\begin{array}{l}\frac{658}{8}=82,25 \\
\text { Kategori: Baik }\end{array}$} \\
\hline Baik & 3 & 245 & $37,5 \%$ & \\
\hline Cukup & 2 & 140 & $25 \%$ & \\
\hline Kurang & 0 & 0 & $0 \%$ & \\
\hline Jumlah & 8 & 658 & $100 \%$ & \\
\hline
\end{tabular}

Sumber : Hasil Penelitian diolah (2018)

Tabel 4 menunjukkan bahwa hasil peningkatan kompetensi pedagogik guru dalam menyusun RPP berbasis PPK melalui IHT pada siklus I mendapatkan rata-rata nilai klasikal sebesar 82 yang termasuk dalam kategori Baik yaitu berada pada rentang nilai 71-85. Perolehan kategori amat baik dengan nilai antara 86-100 sebanyak 3 orang guru atau $37,5 \%$. Kategori baik dengan nilai antara 71-85 sebanyak 3 orang guru atau $37,5 \%$. Kategori cukup dengan nilai antara 55-70 sebanyak 2 orang guru atau $25 \%$. Kategori kurang dengan nilai antara 0-54 sebanyak 0 orang guru atau 0\%. Persentase pencapaian kompetensi pedagogik guru pada siklus I mencapai $75 \%$ atau ada 6 orang guru yang sudah kompeten, sedangkan yang belum kompeten mencapai $25 \%$ atau ada 2 orang guru. Hasil penelitian pada siklus I dapat dikatakan Baik, namun belum mencapai persentase secara klasikal sebesar $85 \%$.

\section{Siklus II}

Berdasarkan analisis instrumen keterlaksanaan program kegiatan dapat diketahui hasil keterlaksanaan program kegiatan IHT siklus II, sebagai berikut.

Tabel 5.

Rekapitulasi Keterlaksanaan Program Kegiatan IHT Siklus II

\begin{tabular}{|c|c|c|c|c|}
\hline Kategori & Respoden & NA & Persen (\%) & Ket. \\
\hline Amat Baik & 6 & 565 & $75 \%$ & \multirow{5}{*}{$\begin{array}{l}\qquad \frac{712}{8}=89 \\
\text { Kategori: Amat Baik }\end{array}$} \\
\hline Baik & 1 & 82 & $12,5 \%$ & \\
\hline Cukup & 1 & 65 & $12,5 \%$ & \\
\hline Kurang & 0 & 0 & $0 \%$ & \\
\hline Jumlah & 8 & 712 & $100 \%$ & \\
\hline
\end{tabular}

Sumber : Hasil Penelitian diolah (2018)

Tabel 5 menunjukkan bahwa hasil keterlaksanaan program kegiatan IHT pada siklus II mendapatkan rata-rata nilai klasikal sebesar 89 yang termasuk dalam kategori Amat Baik yaitu berada pada rentang nilai 86-100. Perolehan kategori amat baik dengan nilai antara 86-100 sebanyak 6 responden atau $75 \%$. Kategori baik dengan nilai antara 
71-85 sebanyak 1 responden atau $12,5 \%$. Kategori baik dengan nilai antara 55-70 sebanyak 1 responden atau $12,5 \%$. Kategori kurang dengan nilai antara 0-54 sebanyak 0 responden atau $0 \%$.
Berdasarkan analisis instrumen kompetensi pedagogik guru dapat diketahui hasil peningkatan kompetensi pedagogik guru dalam menyusun RPP berbasis PPK melalui IHT pada siklus II, sebagai berikut.

Tabel 6.

Rekapitulasi Kompetensi Pedagogik Guru dalam Menyusun RPP berbasis PPK Pada Siklus II

\begin{tabular}{|c|c|c|c|c|}
\hline Kategori & Respoden & NA & Persen (\%) & Ket. \\
\hline Amat Baik & 6 & 565 & $75 \%$ & \multirow{5}{*}{$\begin{array}{l}\qquad \frac{720}{8}=90 \\
\text { Kategori: Amat Baik }\end{array}$} \\
\hline Baik & 1 & 85 & $12,5 \%$ & \\
\hline Cukup & 1 & 70 & $12,5 \%$ & \\
\hline Kurang & 0 & 0 & $0 \%$ & \\
\hline Jumlah & 8 & 720 & $100 \%$ & \\
\hline
\end{tabular}

Sumber : Hasil Penelitian diolah (2018)

Tabel 6 menunjukkan bahwa hasil peningkatan kompetensi pedagogik guru dalam menyusun RPP berbasis PPK melalui IHT pada siklus II mendapatkan rata-rata nilai klasikal sebesar 90 yang termasuk dalam kategori Amat Baik yaitu berada pada rentang nilai 86-100. Perolehan kategori amat baik dengan nilai antara 86-100 sebanyak 6 orang guru atau $75 \%$. Kategori baik dengan nilai antara 71-85 sebanyak 1 orang guru atau $12,5 \%$. Kategori cukup dengan nilai antara 55-70 sebanyak 1 orang guru atau $12,5 \%$. Kategori kurang dengan nilai antara 0-54 sebanyak 0 orang guru atau $0 \%$. Persentase pencapaian kompetensi pedagogik guru pada siklus II mencapai $87,5 \%$ atau ada 7 orang guru yang sudah kompeten, sedangkan yang belum kompeten mencapai $12,5 \%$ atau ada 1 orang guru. Hasil penelitian pada siklus II dapat dikatakan Amat Baik melebihi kompetensi yang dikehendaki secara individu minimal Baik dan sudah melebihi persentase kompetensi pedagogik guru secara klasikal sebesar $85 \%$.

\section{Pembahasan}

Pembahasan hasil penelitian didasarkan pada hasil penelitian prasiklus, siklus I dan siklus II. Hal-hal yang dibahas yaitu peningkatan kompetensi pedagogik guru dalam menyusun RPP berbasis PPK sebelum dan sesudah dilaksanakannya program kegiatan IHT yang dapat dijabarkan sebagai berikut:

Kompetensi pedagogik guru dalam menyusun RPP berbasis PPK sebelum diterapkan program kegiatan IHT mendapat skor rata-rata sebesar 64 yang termasuk dalam kategori Cukup yaitu berada pada rentang skor 55-70. Hal ini dapat dilihat dari 8 guru terdapat $25 \%$ atau ada 2 orang guru 
yang sudah kompeten, sedangkan yang belum kompeten mencapai $75 \%$ atau ada 6 orang guru. Hasil tersebut menunjukkan bahwa pada pra tindakan secara klasikal kompetensi pedagogik guru dalam menyusun RPP berbasis PPK belum mencapai kompetensi yang dikehendaki.

Masih belum tercapainya kompetensi pedagogik guru dalam menyusun RPP berbasis PPK disebabkan guru belum memahami komponen dan prinsip-prinsip penyusunan RPP. Hal ini terbukti dari hasil RPP yang disusun guru masih banyak yang belum lengkap seperti tidak adanya media pembelajaran, tidak ada lembar kerja maupun evaluasi beserta kunci jawabannya, dan tidak adanya instrumen penilaian beserta rubrik penilaiannya. Selain itu dalam mengembangkan indikator pencapaian kompetensi, guru masih kesulitan karena belum memahami taksonomi bloom hasil belajar aspek pengetahuan, sikap, dan keterampilan. Dalam langkah-langkah pembelajarannya pun belum menunjukkan sintaks model pembelajaran yang dipilih. Begitu juga RPP yang disusun guru belum mengintegrasikan penguatan pendidikan karakter, terlihat dari tujuan pembelajaran dan langkahlangkah pembelajarannya tidak mencantumkan pendidikan karakter. Padahal program tersebut diberlakukan cukup lama dan juga diberikan pada kegiatan pelatihan. Hasil RPP yang disusun guru hanya meng-copy paste atau membeli dari rekan sejawatnya dan juga ada yang mengambil (download) RPP dari internet. Hal ini dikarenakan guru enggan menyusun RPP karena banyak tugas yang harus dikerjakan sehingga dengan menyusun RPP dapat mengganggu proses belajar mengajar di kelas. Namun ada juga sebagian guru yang membuat RPP sendiri meskipun masih ada beberapa kelemahan-kelemahan.

Setelah diberikan tindakan siklus I melalui program kegiatan IHT, kompetensi pedagogik guru dalam menyusun RPP berbasis PPK mengalami peningkatan dengan skor rata-rata sebesar 82 atau kategori Baik dibandingkan pada pra tindakan hanya sebesar 64 atau kategori Cukup. Secara klasikal persentase kompetensi pedagogik guru pada pra tindakan sebesar 25\% meningkat pada siklus I sebesar $75 \%$. Terbukti ada peningkatan persentase kompetensi pedagogik guru sebesar $50 \%$. Hasil penelitian pada siklus I dapat dikatakan Baik, namun masih ada 2 orang guru yang memiliki kompetensi kategori cukup padahal kompetensi yang dikehendaki secara individu minimal Baik dan belum mencapai persentase secara klasikal sebesar $85 \%$.

Belum tercapainya kompetensi pedagogik guru dalam menyusun RPP berbasis PPK pada siklus I secara klasikal disebabkan belum maksimalnya keterlaksanaan program kegiatan IHT yang diterapkan kepala 
sekolah. Kepala sekolah belum maksimal dalam membimbing dan mengarahkan/ menggerakkan guru dalam menyusun maupun memperbaiki RPP berbasis PPK. Hal ini disebabkan kepala sekolah belum maskimal dalam mengarahkan dan menggerakkan guru untuk meningkatkan kompetensinya, meningkatkan pengetahuan dan keterampilan guru, serta belum melakukan kerjasama kepada guru yang tingkat kompetensinya lebih tinggi untuk membimbing rekan sejawatnya yang tingkat kompetensinya rendah dalam menyusun RPP berbasis PPK. Hal ini berdampak pada 2 orang guru yang belum mencapai kompetensi yang dikehendaki karena guru belum menggunakan kata kerja operasional sesuai taksonomi bloom dalam merumuskan indikator pencapaian kompetensi dan tujuan pembelajaran serta belum mengintegrasikan penguatan pendidikan karakter dalam kegiatan pembelajaran, guru kesulitan dalam menentukan media pembelajaran, dan guru belum membuat LK dan lembar evaluasi dalam menentukan penilaian hasil pembelajaran.

Setelah diadakan refleksi lebih mendalam terhadap hasil tindakan siklus I dengan menerapkan program kegiatan IHT dapat dikatakan bahwa kompetensi guru dalam menyusun RPP berbasis PPK mengalami peningkatan yang signifikan dengan skor rata-rata sebesar 90 atau kategori Amat Baik dibandingkan pada siklus I hanya sebesar 82 atau kategori Baik. Secara klasikal persentase kompetensi pedagogik guru pada pra tindakan sebesar $25 \%$, meningkat pada siklus I sebesar $75 \%$, dan meningkat secara signifikan pada siklus II sebesar $87,5 \%$. Terbukti ada peningkatan persentase kompetensi pedagogik guru sebesar $62,5 \%$. Hasil penelitian pada siklus II dapat dikatakan Amat Baik melebihi kompetensi yang dikehendaki secara individu minimal Baik dan sudah melebihi persentase secara klasikal sebesar $85 \%$.

Terjadinya peningkatan kompetensi pedagogik guru dalam menyusun RPP berbasis PPK secara klasikal disebabkan kepala sekolah sudah melaksanakan program kegiatan IHT dengan Amat Baik terbukti dari keterlaksanakan program kegiatan IHT yang berjalan dengan maksimal. Hal ini dikarenakan pada siklus II kepala sekolah sudah melaksanakan rekomendasi hasil refleksi siklus I. Pada siklus II kepala sekolah dan rekan sejawat membimbing guru/rekannya pada tiap kelompok yang mengalami kesulitan dalam menyusun RPP berbasis PPK. Kepala sekolah mampu meningkatkan kesadaran guru akan tanggung jawabnya dalam kelompok. Hal ini menjadikan guru mampu mempelajari tugasnya dengan baik dalam kelompok. Berkat bimbingan serta penguatan dari kepala sekolah dan rekan sejawat yang 
kompetensinya lebih tinggi, guru mampu merumuskan indikator pencapaian kompetensi dan tujuan pembelajaran menggunakan kata kerja operasional sesuai taksonomi bloom, sudah mengintegrasikan penguatan pendidikan karakter dalam kegiatan pembelajaran, sudah mampu menentukan media pembelajaran, dan sudah membuat LK dan lembar evaluasi dalam menentukan penilaian hasil pembelajaran.

Dengan demikian penerapan IHT berdampak pada presentase kompetensi pedagogik guru yang ditandai dengan peningkatan kompetensi pedagogik guru dalam menyusun RPP berbasis PPK. Hal tersebut sesuai dengan pendapat Depdikbud (2015:19) bahwa strategi pembinaan melalui IHT dilakukan berdasarkan pemikiran bahwa sebagian kemampuan dalam meningkatkan kompetensi dan karir guru tidak harus dilakukan secara eksternal, tetapi dapat dilakukan oleh guru yang memiliki kompetensi kepada guru lain yang belum memiliki kompetensi.

Selain itu keterlaksanaan program kegiatan IHT yang dilakukan kepala sekolah efektif dalam meningkatkan kompetensi pedagogik guru dalam menyusun RPP berbasis PPK. Hal tersebut sesuai dengan pendapat Mulyasa (2013:99) bahwa peran kepala sekolah adalah sebagai manajer yaitu kepala sekolah dapat memfasiltasi dan memberikan kesempatan yang luas kepada para guru untuk dapat melaksanakan kegiatan pengembangan profesi melalui berbagai kegiatan pendidikan dan pelatihan, baik yang dilaksanakan di sekolah atau melalui kegiatan pendidikan dan pelatihan di luar sekolah.

Berdasarkan hasil penelitian dan pembahasan di atas menunjukkan bahwa dengan menerapkan In House Training terbukti dapat meningkatkan kompetensi guru SDN Gelam 1 Kabupaten Sidoarjo dalam menyusun RPP berbasis PPK. Dari hasil penelitian tersebut, penelitian ini sudah dapat dikatakan berhasil. Hal ini berdasarkan hasil pengisian instrumen peningkatan kompetensi pedagogik guru dan instrumen keterlaksanaan program pada tiap siklus menunjukkan adanya peningkatan yang signifikan dan sudah melebihi ketuntasan yang dikehendaki.

\section{SIMPULAN}

Berdasarkan hasil penelitian tindakan sekolah selama dua siklus dapat disimpulkan sebagai berikut:

Keterlaksanaan program kegiatan In House Training terbukti efektif dalam meningkatkan kompetensi pedagogik guru SDN Gelam 1 Kabupaten Sidoarjo dalam menyusun RPP berbasis PPK. Hal ini terlihat dari hasil keterlaksanaan program kegiatan In House Training pada siklus I mendapatkan skor rata- 
rata sebesar 80 atau kategori Baik meningkat pada siklus II sebesar 89 atau kategori Amat Baik. Terbukti ada peningkatan hasil keterlaksanaan program kegiatan In House Training sebesar $9 \%$.

Penerapan In House Training terbukti dapat meningkatkan kompetensi pedagogik guru SDN Gelam 1 Kabupaten Sidoarjo dalam menyusun RPP berbasis PPK. Hal ini terlihat dari perolehan skor rata-rata pada pra tindakan sebesar 64 atau kategori Cukup, meningkat pada siklus I sebesar 82 atau kategori Baik, dan meningkat secara signifikan pada siklus II sebesar 90 atau kategori Amat Baik. Secara klasikal persentase kompetensi pedagogik guru pada pra tindakan sebesar 25\%, meningkat pada siklus I sebesar 75\%, dan meningkat secara signifikan pada siklus II sebesar 87,5\%. Terbukti ada peningkatan persentase kompetensi pedagogik guru sebesar $62,5 \%$.

\section{DAFTAR PUSTAKA}

Arikunto, Suharsimi. 2010. Prosedur Penelitian Suatu Penelitian Pendekatan Praktek-Cet.14. Jakarta: Rineka Cipta.

Depdikbud. $2015 . \quad K e b i j a k a n$ Pengembangan Profesi Guru. Jakarta: Badan Pengembangan Sumber Daya Manusia Pendidikan dan Kebudayaan dan Penjaminan Mutu Pendidikan.

Hendarman. 2017. Konsep dan Pedoman Penguatan Pendidikan Karakter Tingkat
Sekolah Dasar dan Sekolah Menengah Pertama. Jakarta: Tim PPK Kemendikbud.

Mulyasa, E. 2013. Standar Kompetensi dan Sertifikasi Guru. Bandung: PT. Remaja Rosdakarya.

Permendikbud Nomor 22 Tahun 2016 tentang Standar Proses Pendidikan Dasar dan Menengah. Jakarta: Badan Standar Nasional Pendidikan (BSNP).

Permendiknas Nomor 16 Tahun 2007 Tentang Standar Kualifikasi Akademik dan Kompetensi Guru. Jakarta: Badan Standar Nasional Pendidikan (BSNP).

Sanjaya, Wina. 2010. Perencanaan dan Desain Sistem Pembelajaran. Jakarta: Kencana Prenada Media Group. 